\title{
DEVELOPING SILENT AND SHADOW ACCOUNTS
}

\section{INTRODUCTION}

The quantity of voluntary, unregulated social, environmental and sustainability reporting (SER hereafter) in the UK and elsewhere has risen substantially in recent years, particularly amongst multinational corporations. Yet such disclosures still fail to satisfy some critics who argue that they are selective and unreliable (see, for example, Adams, 2004; Owen and O’Dwyer, 2005). Contrary to the rhetorical claims which usually accompany modern SER, such disclosures may not augment organisational accountability, and may instead be viewed as managerialist attempts to resist meaningful organisational change and to control and manipulate stakeholder sentiment (see, for example, Owen et al., 2000). Whilst industry itself may promote 'self-policing' voluntary regimes (see, for example, BITC, 2003), some critics argue that much more direct intervention, in the form of mandatory regulation of corporate disclosure (and/or governance) processes, is necessary to improve the quality of modern SER (CORE Coalition, 2003). However, tangible progress in this area has been slow, and the last-ditch abandonment of the government's (already weakened) measures in 2005 has ended any immediate prospect of improvements in mandatory SER in the UK at least.

In the absence of complete and reliable 'official' SER, and given the apparent level of institutional resistance towards this, it seems legitimate to consider whether alternative sources of 'unofficial' corporate accountability information may be used. Such a suggestion is not new; indeed, there is a long history of various forms of what is generally referred to as external social reporting (for detailed reviews, see Gray et al., 1996; Gallhofer and Haslam, 2003). In general terms, the use of such external social reports may be advocated on the grounds that:

Published in Sustainability Accounting and Accountability by Routledge. 
"first, [they] act as a 'balancing view' in the face of the considerable resources that organisations have at their disposal to put their own point of view and to offer their own emphasis on their activities. Secondly, [they] can be motivated by the realisation that if organisations will not discharge their own duty of accountability then it is possible for other bodies to do it on their behalf." (Gibson et al., 2001)

Against the backdrop of a rapid increase in what are arguably flawed corporate SER disclosures, a renewed interest in forms of external social reporting as a counterbalance (or 'counter accounting') ${ }^{1}$ to current practice seems worth pursuing. Moreover, at the same time as concerns have risen over the quality of modern SER, recent advances in information technology and global communications, and the emergence of various 'new social movements' in civil society have greatly increased the availability of 'unofficial' accountability information and in turn improved the scope for practical development of external social reporting.

This chapter focuses on the potential of two relatively recent and emerging forms of external social reports, which, drawing on the work of Gray (1997) and Gibson et al. (2001), may be referred to as 'shadow' and 'silent' accounts. The starting point for silent and shadow accounting lies in the differences which exist between what is usually promised by SER and what is generally delivered. Such differences, if studied more closely, may reveal certain 'gaps' in disclosure, and it is the identification of these gaps, by exploiting the vast increase in public availability

\footnotetext{
${ }^{1}$ While a more explicitly political or emancipatory objective for external social reporting (whereby such disclosures become tools to educate and empower stakeholders, and challenge existing hegemonic social forces) might be thought of as 'counter accounting' (Gallhofer et al., forthcoming), detailed discussion of this concept is beyond the scope of this chapter. Nevertheless, it is clearly an important avenue of research which merits development in its own right (see also Gallhofer and Haslam, 2004; Thomson and Bebbington, 2005). Instead, this chapter focuses solely on what might be regarded as more 'conventionally recognisable' and systematic methods of silent and shadow accounting, that seek to address information gaps by producing accounts based on criteria including completeness and verifiability.
} 
of, and access to, wider sources of information about corporate behaviour, that forms the basis of an argument for alternative forms of silent and shadow disclosures. By comparison to the 'official' social and environmental accountability information contained in SER reports currently being disclosed by the organisation, one may define these disclosures as:

(1) the corresponding 'unofficial' or silent account of corporate SER, compiled from 'nuggets' of relevant information obtained via all other formal corporate disclosure channels, including company annual reports, press releases, marketing campaigns etc., and;

(2) a shadow account consisting of other relevant accountability information that is readily available in the public domain, produced independently of the subject organisation, and published externally from it.

As a possible avenue of empirical development, this chapter explores the potential of silent and shadow accounts and reviews the extent to which both academics and other interested groups have already begun to explore it. The chapter concludes by tentatively outlining the ways such reports might be usefully developed further on a practical level. Before doing so, however, the next section of the chapter establishes in more detail the background to, and basis for, silent and shadow accounts.

\section{MINDING THE GAPS: A BASIS FOR SILENT AND SHADOW ACCOUNTS}

Samples of published SER disclosures have been empirically reviewed in the accounting literature to examine the quality of reporting. Evaluating disclosures is a subjective task that may use a wide range of criteria, but the basic principles of the AA1000 reporting process guidelines (ISEA, 1999), so often used by disclosers to 
legitimise their reports, represent an obvious quality benchmark. Yet even when judged in detail against these guidelines, and similar frameworks such as GRI (Global Reporting Initiative, 2002), disclosures still appear to suffer from significant deficiencies (see, for example, Owen et al., 2001; Stittle, 2002; Belal, 2002; Unerman and Bennett, 2004; Owen and O'Dwyer, 2005). Indeed, the criticism of modern CSR extends further, by questioning the underlying purpose of these 'cutting-edge' voluntary reporting standards and guidelines, in terms of their implicit managerialism (Owen et al., 2000). Together, such concerns point to the existence of a 'gap' between what is demanded and what is delivered by current 'best practice' disclosure regimes (Adams and Evans, 2004). This 'gap' has been described variously as: a 'reportingperformance portrayal gap' (Adams, 2004); an 'assurance expectations gap' (Swift and Dando, 2002), a 'legitimacy gap' (Moerman and Van der Laan, 2005); and as a 'credibility gap' (Dando and Swift, 2003; Owen and O’Dwyer, 2005). The existence of a 'gap' has also been identified by industry-sponsored surveys (see, for example, ECC Kohtes Klewes and Fishburn Hedges, 2003) as well as by leading NGOs (see, for example, Christian Aid, 2003).

It seems that there may be different possible definitions of this gap. In fact, it may be measured in (at least) three different ways. Firstly and most straightforwardly, it may be viewed as the difference between the lack of completeness of reporting and the comprehensive picture of overall social performance initially promised by corporate rhetoric and in voluntary reporting standards. Recent studies, including both samples of several high-profile disclosers (Belal, 2002) as well more detailed examinations of individual companies (Gray, 1997; Gibson et al., 2001; Adams, 2004) have demonstrated in compelling ways that current forms of SER, despite claims to the contrary, continue to be highly selective in what is measured and 
communicated to the reader. We will review the evidence presented in these studies in more detail later in this chapter.

Secondly, if SER disclosers are exhibiting undesirable tendencies towards selective reporting, then the role of external assurance in the process becomes especially important. However, once again critics contend that there are significant shortcomings in this part of the SER process. In their review of a sample of assurance statements, Owen and O'Dwyer (2005) questioned both the independence of the assurance process as well as the extent to which management exerted control over the exercise. Such managerialism drew the authors to the conclusion that assurance statements are "merely more 'value added' for management as they manage key risks imposed by various stakeholder groups who need to be controlled”' (p. 209). The 'gap' identified above may also therefore be seen as the difference between the poor reliability of given assurances and the credibility promised in disclosure.

Finally, the gap between what is demanded and what is delivered by current SER practice can also be construed as the difference between the controls and restrictions placed on dialogue processes and the freedoms and rights of participants promised by dialogue organisers (Owen et al., 2001; Unerman and Bennett, 2004). 'Stakeholder dialogue' appears attractive by implying some kind of 'genuine' consensus-based space for dialogue in which companies will listen and respond to the voices of stakeholders. However, it may instead function as a carefully controlled marketing instrument in which stakeholders, lured in by the illusion of influence, simply 'teach' companies about themselves, enabling companies to 'learn' to identify the most troublesome and/or powerful groups and how to control them more effectively (Thomson and Bebbington, 2005). 
The existence of such gaps in modern SER is a matter of fundamental concern because issues of completeness and reliability of SER are central to notions of stakeholder accountability (Gray et al., 1996) while confidence in, and integrity of, stakeholder dialogues is essential to satisfying notions of stakeholder democracy (O'Dwyer, 2005). Following the basic assumptions of accountability theory, the development of an effective counterpoint to current practice which seeks to evidence the gaps identified above, becomes desirable since an increase in the quantity and quality of information (via silent and shadow accounts) may yield a corresponding increase in accountability (Gray et al., 1996). Having established a motivation for silent and shadow accounts, the next section briefly outlines the history of experimentation with external social reporting and reviews the main academic research undertaken in recent years.

\section{EXPERIMENTS TO DATE IN SILENT AND SHADOW ACCOUNTING:}

Whilst the broad idea of using externally produced 'counter-disclosures' as a remedy against perceived deficiencies in the accountability of corporations is wellestablished, practical experimentation with this idea has been somewhat patchy. Over the last three decades external social reporting has manifested itself in different guises without ever fully establishing itself, while its development has been supported and sustained by more familiar and long-standing cultural traditions, including investigative journalism (Pilger, 2004), as well as (perhaps more significantly) the grass-roots activism of various social movements and campaigning pressure groups (Lubbers, 2003). In recent years, such traditions have been supported by the internet as a medium for the dissemination of 'counter-information' (Gallhofer et al., forthcoming). The significance of such wider cultural phenomena for the development 
of new forms of 'counter-accounting' is worth emphasising. In fact, current experiments with counter accounting and counter information are perhaps more likely to owe their existence to civil society and the work of various campaigning NGOs than to the efforts of accounting academics.

The work of organisations such as Social Audit $\operatorname{Ltd}^{2}$ and Counter Information Services (CIS) in the 1970s are perhaps the most celebrated of the antecedents of modern SER (and counter-SER) practice (see Medawar, 1976; Geddes, 1991; Gray et al., 1996; Gallhofer and Haslam, 2003). The name 'social audit' is perhaps especially eye-catching, and although strictly the intellectual property of the company of the same name (and ultimately misleading - the term social account would have been more accurate) it has endured and persisted in general usage. In essence, both organisations were established to publish 'counter-information' as a response to the (then) perceived absence of, and demand for, accountability disclosures. The output of Social Audit Ltd and CIS was substantial, but it had declined by the mid-1980s, and this continued until the emergence in the late 1980s of the popular phrase 'greenwash'3 (Greer and Bruno, 1996), which reflected growing social and media awareness of possible corporate manipulation of environmental issues (mass awareness of which had been invigorated by headlines about global warming). By the early 1990s, this had turned into a backlash against the early pioneers of ethical consumerism; Body Shop's claims of social and environmental responsibility were especially subject to criticism and even an external 'social audit' (Entine, 2003). In

\footnotetext{
${ }^{2}$ Despite ceasing publication of its external social reports in 1976, Social Audit Ltd continues to operate, although it now focuses more exclusively on the pharmaceutical industry. For more information, see http://www.socialaudit.org.uk.

3 'Greenwash' is now the subject of its own 'awards' and was defined at the 2002 Greenwash Academy Awards as "the phenomenon of socially and environmentally destructive corporations attempting to preserve and expand their markets by posing as friends of the environment and leaders in the struggle to eradicate poverty".
} 
the accounting literature, some research was undertaken to review the impact of pressure groups on published SER (Tilt, 1994), while calls were also made for improved independent 'monitoring' of the activities of multinational corporations (Bailey et al., 1994), which potentially involved some form of regulated external accountability reporting (Bailey et al., 2000).

By the mid 1990s, the fist experiments in modern SER practice were beginning to emerge. As this grew into a rapidly rising groundswell of corporate, governmental and media enthusiasm for voluntary social and environmental reporting, the use of counter-information techniques waned. Although the quantity of emerging SER practice was recognised to relatively low, a sense of optimism drove forward attempts to improve 'best practice'. In academia and beyond, efforts were increasingly directed pragmatically at trying to encourage corporations and assist in the development of the theory and practice of modern SER (see, for example, Zadek et al., 1997).

In an effort to boost the relatively low volume of disclosure at that time, and prompt more critical reflection on the state of SER, Gray (1997) mooted the idea of reviving forms of external social reporting. However, rather than simply reproducing the approach pioneered in the 1970 s by Social Audit Ltd and Counter Information Services, Gray devised a new and intriguingly different form of corporate 'silent' accounting. To illustrate the concept, Gray produced a silent account based on the 1994 annual report of the large pharmaceutical company Glaxo plc. The simple premise of this idea was to identify relevant information from Glaxo's annual report (referred to as 'silent' because such information, although published, was not 'officially' labelled or recognised as SER) and to effectively 'create' a new piece of SER by collating this relevant information in a new document. Silent accounts could 
be seen not only as a cheap and quick way of increasing disclosures, but also as 'greater than the sum of their parts' by (re)creating a picture of organisational accountability based on 'broad' areas of activity concerning four 'key' stakeholders: employees, community, customers and environment; as well a further category covering corporate mission and governance issues. These categories were chosen partly on the grounds that they typically featured in corporate annual reports. Clearly, as Gray himself acknowledged, they were by no means a complete list, but in the absence of more complete and inclusive corporate disclosures, a wider picture of stakeholder accountability could not be easily generated. Indeed, to overcome this problem, Gray appears to envisaged his experiment as an initial test of the feasibility of a more complete and coherent form of organisation-centred SER (see especially, Gray et al., 1997).

By the late 1990s, concerns about the pervasive absence of corporate SER began to gradually diminish, while a new set of concerns grew over the quality of emerging corporate disclosures. To find new ground upon which a critical evaluation of SER might be developed, a number of accounting academics started various separate research projects which sought to develop new forms of external social reporting ${ }^{4}$.

Gray's initial experimentation with silent accounting was radically revised by a group of researchers including the same author to incorporate a form of external social reporting which was termed 'shadow accounts'. Shadow accounting represented a more familiar rediscovery of the external social reports of the 1970s. Crucially, however, in seeking to illuminate further the shortcomings of corporate accountability disclosures, it recognised the increasing quantities of, and access to,

\footnotetext{
${ }^{4}$ See also the 'critical financial analysis' developed and applied to the privatised utilities in the UK by Shaoul (1998).
} 
counter-information in the public domain. Such information could be relatively easily gathered by academic researchers and published, not simply as a separate document, but in parallel with 'unofficial' silent accounts (or, if they were available, 'official' SER), using the same categories and subject headings.

To this end, Gibson et al. (2001) produced a series of combined reports on the activities of well-known UK companies, from different industry sectors, which had yet to produce their own dedicated social or environmental reports. These pioneering silent and shadow accounts presented the reader with a (hitherto unavailable) picture of corporate accountability which directly juxtaposed corporate and non-corporate sources of information. The accounts were deliberately presented to the reader without much additional editorialising or analysis and relied on the information gathering exercise alone for their impact. A second, and perhaps less justifiable, characteristic of these reports was their relatively uncritical use of shadow information sources, which in the Gibson et al. accounts relied mainly on (potentially inaccurate) broadsheet newspaper articles. The shadow account did not independently establish the veracity or, for that matter, qualify the content of some material as allegations rather than accepted fact. Such an approach could in a strict sense be construed as potentially libellous, but more importantly it risked implying a doublestandard whereby shadow sources did not need to be subjected to the same scrutiny as corporate sources. Nevertheless, despite its possible shortcomings, putting combined silent and shadow reports together in this way served as a compelling basis for revealing significant gaps in the completeness of corporate (non)disclosure, as well as the extent to which easily available shadow information could be used, both to illuminate the gaps in knowledge of aspects of corporate behaviour missing from 
disclosures as well as to challenge the (mis)representation of events portrayed in corporate reports.

Around the same time as the notions of silent and shadow accounting were being developed by Gray and others in the mid to late 1990's, a separate project on external social reporting was undertaken by Adams (2004) to explore what she termed the 'reporting-performance portrayal gap'. Adams' case study, in contrast to the 'silent' study of a 'non-reporting' corporation by Gray (1997), examined a corporation (known only by the pseudonym 'Alpha') that had been already been producing SER for some years. Using the accountability framework set out in the established social and environmental reporting standards of AA1000, Adams analysed Alpha's published SER (for the years 1993 and 1999) by contrasting it against what the author was able to research and uncover about the chosen company from a wide range of (carefully verified) 'shadow' external information sources for the same time periods. In a broadly similar fashion to the experiments of Gibson et al. (2001), Adams uses (and identifies in some detail) a wide range of sources of 'shadow' information to illuminate the shortcomings of completeness present in SER disclosures. Like the Gibson et al. research, these shortcomings included situations where (a) shadow information was found to conflict in some way with the comparable corporate account, or (b) where shadow information cast light on something material to stakeholders which was not included in the SER report.

Perhaps more than any other recent experiments in external social reporting, Adams' research evidenced clear deficiencies in completeness in the company's voluntary SER. Although the rhetoric of Alpha's later (and supposedly 'improved') 1999 corporate SER report examined by Adams seemed to imply a narrowing of the 'gap', her study found little evidence of this, and she concluded that, despite several 
years of development, the disclosure produced by the company under examination still suffered from substantial completeness deficiencies, as well as significant audit and credibility flaws. By comparison, Adams' work is more analytical and drew its own conclusions in a more 'editorialised' style than Gibson et al. accounts. However, at the same time, for a number of entirely justifiable reasons (both legal and intellectual), the identity of Adams' chosen company was concealed in the paper, whilst the Gibson et al. reports left the company identities (and arguably some of the wider value of the work to a non-academic audience) preserved.

Table 1 below attempts to summarise the main characteristics of each of the three experiments reviewed earlier. The basic format of these experiments is compared, as well the extent to which each uses an explicit framework. The table also attempts to summarise the coverage of each experiment in examining 'gaps' in completeness, dialogue and assurance. While all three experiments have a clear and understandable focus on exploring notions of completeness, the approach of Adams (2004) is perhaps the most comprehensive because of the way it combines the basis of a recognised framework (i.e. AA1000 and GRI reporting standards) with a relatively wider range of shadow information sources and a more explicitly analytical approach to the exploration of completeness 'gaps'. Adams' work is also commendable in that it acknowledges the importance of other gaps in assurance and dialogue processes (although it does not review these issues in as much depth).

In fairness to the Gray and Gibson et al. experiments, it is important to emphasise that Adams' use of shadow information as an analytical tool is perhaps made easier by the fact that she was comparing shadow information against the weight of a standalone SER report (within which explicit dialogue and assurance processes are supposed to happen) than against a more slight and intangible notion of 
'unofficial' silent accounts (in which such organisational accountability mechanisms may not exist).

Table 1: Recent academic experiments in external social reporting

\begin{tabular}{|c|c|c|c|}
\hline & $\begin{array}{l}\text { Silent accont of } \\
\text { Glaxo plc (Gray, } \\
\text { 1997) }\end{array}$ & $\begin{array}{l}\text { Silent/shadow } \\
\text { accounts of Tesco } \\
\text { and HSBC (Gibson } \\
\text { et al., 2001) }\end{array}$ & $\begin{array}{l}\text { The ethical, social and } \\
\text { environmental reporting- } \\
\text { performance portrayal gap } \\
\text { at 'Alpha' (Adams, 2004) }\end{array}$ \\
\hline Basic format & Silent account & $\begin{array}{l}\text { Separate silent and } \\
\text { shadow accounts - } \\
\text { both with same } \\
\text { structure }\end{array}$ & $\begin{array}{l}\text { Comparison of standalone } \\
\text { SER with shadow information } \\
\text { for years } 1993 \text { and } 1999\end{array}$ \\
\hline Section headings & $\begin{array}{l}\text { Corporate } \\
\text { mission/governance } \\
\text { and four 'key' } \\
\text { stakeholders }\end{array}$ & $\begin{array}{l}\text { Corporate } \\
\text { mission/governance } \\
\text { and four 'key' } \\
\text { stakeholders }\end{array}$ & $\begin{array}{l}\text { (1) Subject headings cover } \\
\text { range of four broad } \\
\text { environmental issues } \\
\text { (2) Overall coverage of key } \\
\text { AA } 1000 \text { and GRI principles }\end{array}$ \\
\hline \multirow{3}{*}{$\begin{array}{l}\text { Sources used } \\
\text { (corporate and } \\
\text { shadow) }\end{array}$} & \multirow[t]{3}{*}{$\begin{array}{l}\text { Company Annual } \\
\text { Report (1994) }\end{array}$} & $\begin{array}{l}\text { Company Annual } \\
\text { Report }(2000)\end{array}$ & $\begin{array}{l}\text { Corporate SER Reports (1993 } \\
\& \text { 1999) }\end{array}$ \\
\hline & & $\begin{array}{l}\text { UK Broadsheet } \\
\text { Newspapers (WWW } \\
\text { and CD-ROMs) }\end{array}$ & \multirow{2}{*}{$\begin{array}{l}\text { Many wider sources from the } \\
\text { WWW: business related, anti- } \\
\text { corporate NGOs, consumer } \\
\text { groups, business and trade } \\
\text { journals, newspaper CD- } \\
\text { ROMs, etc. }\end{array}$} \\
\hline & & $\begin{array}{l}\text { Limited additional } \\
\text { sources from wider } \\
\text { media }\end{array}$ & \\
\hline $\begin{array}{l}\text { Source Material } \\
\text { Presentation }\end{array}$ & $\begin{array}{l}\text { Quoted excerpts } \\
\text { from company } \\
\text { annual report }\end{array}$ & $\begin{array}{l}\text { Quoted excerpts from } \\
\text { company annual } \\
\text { report and shadow } \\
\text { sources }\end{array}$ & $\begin{array}{l}\text { Editorialised summaries and } \\
\text { selective comparisons of SER } \\
\text { and shadow information }\end{array}$ \\
\hline $\begin{array}{l}\text { Analytical framework } \\
\text { used }\end{array}$ & $\begin{array}{l}\text { Implicit notion of } \\
\text { stakeholder } \\
\text { accountability }\end{array}$ & $\begin{array}{l}\text { Stakeholder } \\
\text { accountability }\end{array}$ & AA1000/GRI key principles \\
\hline $\begin{array}{l}\text { Coverage of } \\
\text { silent/shadow } \\
\text { accounting } \\
\text { (in)completeness }\end{array}$ & $\begin{array}{l}\text { No direct evidence, } \\
\text { some } \\
\text { accompanying } \\
\text { discussion on } \\
\text { incompleteness }\end{array}$ & $\begin{array}{l}\text { Presentation of silent } \\
\text { and shadow } \\
\text { information in } \\
\text { parallel, no follow-up } \\
\text { analysis }\end{array}$ & $\begin{array}{l}\text { Detailed comparison between } \\
\text { and analysis of SER and } \\
\text { shadow information (but only } \\
\text { where shadow information } \\
\text { was available) }\end{array}$ \\
\hline $\begin{array}{l}\text { Coverage of corporate } \\
\text { SER credibility/ } \\
\text { assurance }\end{array}$ & $\begin{array}{l}\text { None (not } \\
\text { applicable }\end{array}$ & Not covered & $\begin{array}{l}\text { Brief outline of quality of } \\
\text { audit procedures }\end{array}$ \\
\hline $\begin{array}{l}\text { Treatment of shadow } \\
\text { accounting } \\
\text { completeness and } \\
\text { reliability }\end{array}$ & Not applicable & $\begin{array}{l}\text { Shadow sources not } \\
\text { qualified or } \\
\text { independently } \\
\text { verified }\end{array}$ & $\begin{array}{l}\text { All shadow sources } \\
\text { independently verified }\end{array}$ \\
\hline $\begin{array}{l}\text { Coverage of } \\
\text { embeddedness/ } \\
\text { stakeholder dialogue }\end{array}$ & $\begin{array}{l}\text { None (not } \\
\text { applicable) }\end{array}$ & Not covered & $\begin{array}{l}\text { Brief coverage of (lack of) } \\
\text { evidence of dialogue }\end{array}$ \\
\hline $\begin{array}{l}\text { Treatment of } \\
\text { corporate identity }\end{array}$ & $\begin{array}{l}\text { Corporate identity } \\
\text { not concealed }\end{array}$ & $\begin{array}{l}\text { Corporate identities } \\
\text { not concealed }\end{array}$ & Corporate identity concealed \\
\hline
\end{tabular}




\section{COUNTER-INFORMATION, NEW SOCIAL MOVEMENTS AND CIVIL}

\section{SOCIETY}

Before further drawing together the strands of 'silent' and 'shadow' accounting research reviewed so far, it is important to first develop the point raised earlier in this chapter concerning the significant and ongoing contribution of other parts of civil society to forms of external social reporting. As the previous section of the chapter noted, it can be argued that much of what academic accountants have done to evidence gaps in existing SER has in fact relied on wider sources of counterinformation available in the public domain. The general theme of corporate abuse of power has become increasingly prominent (see, for example, Klein 2000; Monbiot, 2000; Hertz, 2001), as has popular interest in the issue in specific settings such as the fast-food or supermarket industries (see, for example, Schlosser, 2002; Blythman, 2004). In addition, though, this rising mass disapproval towards corporate (mis)behaviour has roots in more politically active parts of civil society. Public discontent with the social and environmental impacts of modern capitalism has been expressed through the activities of what may be termed 'new social movements'. Such social movements include the activities of a range of campaigning pressure groups and other non-governmental organisations (NGOs). The work of campaigning NGOs in influencing the behaviour of corporations has for many years received relatively little attention in the accounting literature (although see, especially, Tilt, 1994).

Such work is clearly a potentially vast source of information for shadow accounts, and indeed the role of campaigning NGOs in mobilising corporate counterinformation via the internet has now received more attention from some accounting 
academics (Gallhofer et al., forthcoming). These movements seek to raise global awareness of social and environmental issues and to hold organisations more accountable by mobilising grass-roots action against corporations and governments (Crossley, 2003). Globalisation, the emergence and spread of internet technology and the growth of organised, grass-roots social networks have all conspired to create the widespread public demand for counter-information about institutional accountability practices (Lubbers, 2003). Anti-corporate websites allow disgruntled individuals the chance to air their views to a global audience and to involve themselves and share information with diffuse networks of like-minded people (Kahn and Kellner, 2005). 'Anti-corporate' campaigning groups such as Corporate Watch $^{5}$ run websites that act as 'portals' to a range of electronic information sources, allowing easy access to a huge amount of information.

The significance of 'grievances' against modern capitalism and globalization within 'new social movements', and their focus on perceived moral deficiencies of corporate behaviour (Crossley, 2003) resonates strongly with the work of the critical accounting community (see, for example, Cooper et al., 2003; Everett, 2003). Indeed, NGOs that have chosen to produce their own 'shadow' or 'counter' disclosures of specific corporate targets usually choose corporations that already provide high levels of voluntary SER. By arguably failing to close the 'gap' required to reassure or convince stakeholders, SER is interpreted and labelled by external stakeholder representatives as more 'greenwash', and thus may actually serve to mobilise action. One strategy that seems to be increasingly adopted by some NGOs to tackle such

\footnotetext{
${ }^{5}$ See www.corporatewatch.org.uk.
} 
corporate 'propaganda' is to publish their own counter-information ${ }^{6}$ in ways which directly confront existing corporate-controlled SER.

Like the academic studies discussed in the previous section, these external 'shadow' reports seek to the collect and present wider external sources of information about the social and environmental impacts of the chosen corporation. To this author's knowledge, the most active NGO in this area (in terms of publishing specific corporate 'shadow' reports) is Friends of the Earth (FoE). To date FoE (in collaboration with other more specific issues-based activist groups) has published a number of external social reports such as Failing the Challenge: The Other Shell Report 2002 (FoE, 2003a) and the Amec Counter Report 2002 (FoE, 2003b). Shell, of course, is a particularly high-profile discloser of SER and its publications have frequently been held up as an example of both 'best practice' and 'bad practice'. The FoE document was ostensibly a retrospective review of Shell's 2002 social report, which, had it done so, would have reflected the general approach taken in the academic accounting domain by Adams (2004) and to some extent by Gibson et al. (2001). However, an examination of the content of the report reveals a series of short narrative 'case-studies' of various communities directly affected by Shell's multinational operations. The scope and structure for these narratives was not explicitly pre-defined. Some evidence was based on current data, while other information appeared to relate to events that took place much earlier than 2002; some views were supported by quotes from community members, others were not; and there was no overall 'mapping' of Shell's worldwide operations. Only two pages out of the 28-page report dealt with claims made by Shell in its own disclosures, and while the document

\footnotetext{
${ }^{6}$ NGOs involved in activism and advocacy will typically use a number of different strategies to engage with corporations (Bliss, 2002).
} 
explicitly acknowledged the existence of wider sources of third-party evidence on Shell's behaviour, it does not make use of most of this evidence.

Rather than using their report to simply state the difference between what Shell itself 'says' and what other stakeholders 'know about' Shell, FoE's approach is heavily editorialised, in that FoE's objective is really to (in the words of Shell's own PR campaign) 'tell Shell' what it thinks of Shell's behaviour. This may of course be an entirely justifiable objective in itself: the notion of an explicit 'counter-accounting' that is intentionally partial and political is well-established, as this chapter has acknowledged. Consequently, and in sharp contrast to the work of Adams (2004), the FoE report does not evaluate Shell's own SER in a systematic way using the principles of disclosure standards such as AA1000. It also fails to address some novel aspects of Shell's SER practices, such as its web-based dialogue (but see Unerman and Bennett, 2004). Whilst FoE are in many ways right to draw attention to the selective bias and unreliability of the Shell report, they counter this with what is arguably an even more selective and unreliable report of their own. The report is therefore perhaps better viewed as an interesting piece of 'investigative journalism' or even 'counter-propaganda' that is intentionally provocative, generates media coverage, and creates a platform for the 'voices' of marginalised stakeholders to be heard.

Whilst FoE's work falls short as a piece of systematic 'shadow' accounting, other examples of NGO-based reporting appear to exhibit characteristics which more closely resemble the academic experiments discussed earlier. At the same time as British American Tobacco (BAT) was publishing its first social report (BAT, 2002), the anti-smoking pressure group Action against Smoking and Health (ASH) produced British American Tobacco - the Other Report to Society (ASH, 2002a). In line with 
most modern SER, BAT claimed that their report was constructed using both the AA1000 accounting and audit standard and the GRI disclosure guidelines. It included considerable efforts to engage directly with stakeholders through dialogue processes, and was also 'verified' by an external consultant. In response, the ASH document closely shadowed these processes and attempted to evidence in detail areas of disclosure where the BAT report fell short of the AA1000 guidelines. The ASH report criticised the scope of the social report, arguing that BAT had failed to identify its most important stakeholders. It also questioned the credibility and transparency of the report, concluding that BAT had failed to provide reliable information to stakeholders. ASH also criticised the management of the company's 'stakeholder dialogue' process (a dialogue to which it had been invited to but chose to ignore) on the grounds that there were "virtually no areas where BAT and ASH can find common cause - we characterise BAT's relationship with public health as a zero-sum game" (ASH, 2002b).

In addition to the reports published by ASH, BAT's SER disclosures have also attracted the attention of accounting academics. Moerman and Van Der Laan (2005) echo the work of ASH in critically reviewing BAT's 2002 social report, while the assurance gap in BAT's reporting has also been criticised elsewhere (Owen and O’Dwyer, 2005). Like ASH, Moerman and Van der Laan also use AA1000 and GRI frameworks as a benchmark, and their critique of the 'smoke and mirrors' of BAT's disclosures shares much in common with the conclusions offered by ASH. However, (crucially, from the perspective of this chapter) they do not set out to explicitly compare BAT's report with external 'shadow' reports. Their work focuses more on discussing the significance of the existence of gaps in BAT's reporting rather than filling in those gaps with shadow information. 
Table 2 below follows the broad format of table 1 earlier in seeking to distil the basic characteristics of the NGO-based shadow reports reviewed here. As one might expect, NGO-based reporting appears to be more adversarial in its use of shadow information as 'ammunition' against its corporate target. This stance appears to be taken at the expense of a relative weakness in the reports to systematically analyse completeness, assurance and dialogue gaps in SER using a clear accountability framework. Nevertheless, the ASH report is potentially interesting in its specific focus on social reporting and the standards and frameworks used to construct the BAT report. ASH also demonstrate an awareness of the importance of dialogue and assurance processes. In these respects the ASH report is much more closely aligned with the experimentation in the accounting literature reviewed earlier. 
Table 2: Recent NGO experiments in external social reporting

\begin{tabular}{|c|c|c|}
\hline & $\begin{array}{l}\text { Failing the Challenge: The } \\
\text { Other Shell Report (FoE, } \\
\text { 2003a) }\end{array}$ & $\begin{array}{l}\text { British American Tobacco: The Other } \\
\text { Report to Society (ASH, 2002a) }\end{array}$ \\
\hline Basic format & $\begin{array}{l}\text { Glossy 28-page 'mimic' of Shell } \\
\text { SER publication }\end{array}$ & Simple 46-page text \\
\hline Section headings & $\begin{array}{l}\text { Emphasis on 'real-life' accounts } \\
\text { based on a selective coverage of } \\
\text { Shell's impact in specific } \\
\text { locations } \\
\text { No stakeholder or issues based } \\
\text { section headings }\end{array}$ & $\begin{array}{l}\text { (1) Issues based headings } \\
\text { (2) Impact in specific locations } \\
\text { (3) Sub-headings covering implications } \\
\text { for BAT's social accounting process }\end{array}$ \\
\hline Additional Sources & $\begin{array}{l}\text { Not explicitly defined in scope, } \\
\text { but all referenced. A range of } \\
\text { media and counter-information } \\
\text { sources }\end{array}$ & $\begin{array}{l}\text { Not explicitly defined in scope, but wide } \\
\text { range of referenced sources covering } \\
\text { tobacco industry including government } \\
\text { and scientific evidence, trade, medical } \\
\text { and marketing journals, anti-tobacco } \\
\text { campaign groups etc. }\end{array}$ \\
\hline Analytical framework & Selective comparisons & AA1000 principles \\
\hline $\begin{array}{l}\text { Coverage of corporate } \\
\text { SER (in) completeness }\end{array}$ & $\begin{array}{l}\text { Many comparisons between } \\
\text { shadow information and SER } \\
\text { but no systematic coverage }\end{array}$ & $\begin{array}{l}\text { Draws on shadow and 'silent' evidence to } \\
\text { demonstrate shortcomings in } \\
\text { completeness with reference to AA1000 } \\
\text { principles }\end{array}$ \\
\hline $\begin{array}{l}\text { Coverage of corporate } \\
\text { credibility/ assurance } \\
\text { process }\end{array}$ & None & $\begin{array}{l}\text { No detailed review - limited to short } \\
\text { recommendations }\end{array}$ \\
\hline $\begin{array}{l}\text { Coverage of corporate } \\
\text { stakeholder dialogue } \\
\text { processes }\end{array}$ & None & $\begin{array}{l}\text { Partial review focusing on direct } \\
\text { experience of shortcomings indialogue } \\
\text { process; reasons for rejecting } \\
\text { participation explained }\end{array}$ \\
\hline $\begin{array}{l}\text { Treatment of shadow } \\
\text { accounting reliability: }\end{array}$ & $\begin{array}{l}\text { Sources are referenced but not } \\
\text { verified }\end{array}$ & Sources are referenced but not verified \\
\hline
\end{tabular}

The next section of the chapter attempts to identify the limitations and difficulties that are likely to be faced by NGOs, academics and others who might seek to produce such reports. Taking this into account, a tentative structure for future experimentation with shadow and silent accounting is then presented.

\section{TOWARDS A FRAMEWORK FOR SILENT AND SHADOW ACCOUNTS}

A review of experiments to date with forms of silent and shadow accounting suggests that academics and NGOs appear to share an common interest in illuminating the 
shortcomings of current SER, with a focus on evidencing (at least some) gaps in the completeness of published disclosures. By comparison, however, there are some interesting differences. The experiments of academics such as Gibson et al. (2001) and more especially Adams (2004) appear to offer more rigour and systematic coverage; they are more solidly grounded and promising theoretically, in contrast to the emerging 'counter accounting' reports of NGOs like FoE and ASH which appear to be (quite deliberately) partisan and adversarial. This raises important questions (which are beyond the scope of this chapter) about the nature and objectives of external social reporting, including whether such reports should subscribe to the types of standards of completeness and reliability used to measure the quality of (corporate) SER, or instead abandon such benchmarks and restrict external social reporting to the deliberately selective presentation of 'counter information'. Indeed, in the context of some recent initiatives by high profile campaigning NGOs to move away from adversarial tactics and seek to develop more collaborative relationships with corporations, the development of more consistent, complete and reliable forms of external social reporting could be viewed as a useful platform for constructive dialogue.

Putting such theoretical questions to one side, it is clear that NGO-based reports, despite their possible differences in motive, style and substance, will continue to provide a valuable resource for collating more systematic shadow accounts, particularly in circumstances where they are produced by organisations (such as FoE) which are directly active in campaigning for improvements in corporate accountability, and which conduct their own primary research. The ex post experiments of Gibson et al. (2001) and Adams (2004) could therefore be revisited and developed further by using new empirical subjects. However, academic 
involvement in silent and shadow accounting could also extend more directly towards civil society by encouraging and offering guidance to NGOs to produce more consistent and complete shadow accounts. In the same way that academics have sought to develop organisation-centred SER by experimenting with organisations, there is some pragmatic justification for this idea. Publishing shadow accounts through NGOs may also help to protect academics from the possible risks surrounding the use of counter information and the threat of libel action (although the onus would still be on researchers to either qualify or verify any allegations being reprinted); while the outputs from such experiments could also be disseminated more widely to a non-academic audience. Of course, how these reports should be put together, and how they are used within an overall political strategy by NGOs, are clearly important issues, especially as there appears to be a lack of consistency amongst the NGO reports reviewed in this chapter. On these particular questions, it may be that some academic guidance on the development and practical application of silent and shadow accounts would be useful ${ }^{7}$.

Drawing on the discussion so far, what lessons may be learnt in terms of the practical guidelines that silent and shadow accounting should follow? In some ways the most straightforward answer to this question (and following closely from methods employed by Adams, 2004) is to apply to silent and shadow accounts the relevant principles that are currently used to guide organisation-centred SER. These include the current AA1000 and GRI guidelines and standards, which, whilst perhaps not 'perfect', are nevertheless used to good effect by academics to critique current SER. In doing so, it seems fair to acknowledge that both silent and shadow accounting

\footnotetext{
${ }^{7}$ It is even possible to envisage wider efforts to improve the legitimacy of shadow reporting, for example through the invitation to submit shadow reports to existing corporate SER reporting awards schemes, or the establishment of expert-reviewed 'shadow reporting awards'.
} 
share the need for clear and explicit frameworks which seek to construct, in as complete and transparent a way as is possible, a picture of organisational accountability based on the limits of the available information. Managing the potentially vast range of available information sources from a diverse range of accountability mechanisms requires additional careful thought. In putting to one side readily available corporate SER disclosures, the challenge is to identify (within defined boundaries of scope) and scour (within defined boundaries of availability and verifiability) relevant accountability mechanisms and other information sources for 'nuggets' of useful and material information, and at the same time one might also seek to highlight those places where such nuggets do not exist. For silent accounts, this is much more restrictive in focusing on the reconstruction of organisational (non)disclosure, but in general terms, one may perhaps conceive of a series of 'layers' which silent and shadow accounts might consist of. These layers may include the following:

(1) statement of objectives (including engagement/follow-up strategy with corporation);

(2) identification of stakeholders (and basis of including/ignoring them);

(3) organisational accountability mechanisms examined;

(4) wider shadow information sources used (or rejected?), including clear qualification of sources where they are allegations rather than verifiable fact;

(5) assessment of completeness of corporate (and shadow) accounts, possibly including 'maps' of information sources and availability of sources;

(6) assessment of formal stakeholder dialogue processes and outcomes, including (where available) additional primary evidence from stakeholders; 
(7) assessment of level of assurance offered by corporate (and shadow?) accountability mechanisms;

(8) formal invitation to (or evidence of) feedback to the exercise offered to company management and stakeholders.

The development of this tentative structure in practice is certainly challenging, especially in mapping the potentially large quantity of shadow information sources, and of interpreting and applying the criteria of completeness and reliability. At the same time, though, the availability of relevant information, and the potential for useful collaboration with NGOs and other external social reporting agencies, present many interesting opportunities for future research. 


\section{References}

Action on Smoking and Health (2002a) British American Tobacco - the other report to society, ASH.

Action on Smoking and Health (2002b) BAT social report revisited - ASH comes to $B A T$, ASH.

Adams, C. A. (2004) 'The ethical, social and environmental reporting performance portrayal gap', Accounting, Auditing and Accountability Journal, Vol. 17, No. 5, pp 731-757.

Adams, C. and Evans, R. (2004) "Accountability, Completeness, Credibility and the Audit Expectations Gap", Journal of Corporate Citizenship, Issue 14, pp. 97115.

British American Tobacco (2002) Report to society, BAT.

Bailey, D., Harte, G. and Sugden, R. (1994) Making Transnationals Accountable, Routledge.

Bailey, D., Harte, G. and Sugden, R. (2000) "Corporate disclosure and the deregulation of international investment", Accounting, Auditing and Accountability Journal, Vol. 13, No, 2. pp, 197-218.

Belal, A. (2002) "Stakeholder accountability or stakeholder management? A review of UK firms' social and ethical accounting, auditing and reporting practices", Corporate Social Responsibility and Environmental Management, Vol. 9, No. 1, pp. 8-25.

Bliss, T. (2002) “Corporate advocacy groups: friend or foe?", in Andriof, J. et al. (eds.) (2002) Unfolding Stakeholder Thinking, Greenleaf, pp. 251-267.

Blythman, J. (2004) Shopped: The Shocking Power of British Supermarkets, Fourth Estate.

Business in the Community (2003) Indicators that Count: Social and environmental indicators - a model for reporting impact, BITC.

Christian Aid (2003) Behind the mask: The real face of corporate social responsibility, Christian Aid report.

CORE Coalition (2003) With Rights Come Responsibilities, online: http://www.amnesty.org.uk/business/campaigns/core/index.shtml.

Cooper, C., Neu, D. and Lehman, G. (2003) Globalization and its Discontents: A Concern about Growth and Globalization, Accounting Forum, Vol. 27, No. 4, pp. 359-364.

Crossley, N. (2003) "Even newer social movements? Anti-corporate protests, capitalist crises and the remoralization of society", Organization, Vol. 10, No. 2, pp. 287-307.

Dando, N. and Swift, T. (2003) "Transparency and assurance: Minding the credibility gap", Journal of Business Ethics, Vol. 44, No. 2, pp. 195-200.

ECC Kohtes Klewes and Fishburn Hedges (2003) Global Stakeholder Report 2003.

Entine, J. (2003) A Social and Environmental Audit of Body Shop: Anita Roddick and the Question of Character, online: http://www.entine.com. 
Everett, J. (2003) "Globalization and its New Spaces for (Alternative) Accounting Research", Accounting Forum, Vol. 27, No. 4, pp 400-424.

Friends of the Earth (2003a) Failing the challenge: the other Shell report 2002, FoE.

Friends of the Earth (2003b) Amec Counter Report 2002, FoE.

Global Reporting Initiative (2002) Sustainability reporting guidelines, GRI.

Gallhofer, S. and Haslam, J. (2003) Accounting and Emancipation: Some Critical Interventions, Routledge.

Gallhofer, S. and Haslam, J. (2004) "Accounting and liberation theology: Some insights for the project of emancipatory accounting", Accounting, Auditing and Accountability Journal, Vol. 17, No. 3, pp. 382-407.

Gallhofer, S. Haslam, J., Roberts, C. and Monk, E. (forthcoming) “The Emancipatory Potential of Online Reporting: The Case of Counter Accounting", Accounting, Auditing and Accountability Journal.

Geddes, M. (1991) "The Social Audit Movement" in Owen, D.L. (ed) Green Reporting, Chapman Hall, pp. 215-241.

Gibson, K., Gray, R.H., Laing, Y. and Dey, C.R. (2001) "The Silent Accounts Project: Draft Silent and Shadow Accounts 1999-2000" (separate publications for Tesco plc and HSBC Holdings plc), online: http://www.standrews.ac.uk/ csearweb/aptopractice/silentacc.html

Gray, R.H. (1997) “The Silent Practice of Social Accounting and Corporate Social Reporting in Companies" in Zadek et al. (Eds.) Building Corporate AccountAbility: Emerging Practices in Social and Ethical Accounting, Auditing and Reporting, Earthscan.

Gray, R.H., Dey, C.R., Owen, D., Evans, R. and Zadek, S. (1997) "Struggling with the Praxis of Social Accounting: Stakeholders, Accountability, Audits and Procedures", Accounting, Auditing and Accountability Journal, Vol. 10, No. 3, pp.325-364.

Gray, R., Owen, D. and Adams, C. (1996) Accounting and Accountability, ChapmanHall.

Greer, J. and Bruno, K. (1996) Greenwash: The reality behind corporate environmentalism, Third World Network.

Hertz, N. (2001) The Silent Takeover: Global Capitalism and the Death of Democracy, Heinemann.

ISEA (1999) AccountAbility 1000: A Foundation Standard in Social and Ethical Accounting, Auditing and Reporting, ISEA.

Kahn, R. and Kellner, D. (2005) "Oppositional Politics and the Internet: a critical/reconstructive approach" Cultural Politics, Vol. 1, No. 1, pp. 75-100.

Klein, N. (2000) No Logo, Flamingo.

Lubbers, E. (ed.) (2003) Battling Big Business, Common Courage Press.

Medawar, C. (1976) “The Social Audit: A Political View”, Accounting, Organizations and Society, Vol. 1 No. 4, pp. 389-394. 
Moerman, L. and Van Der Laan, S. (2005) "Social Reporting in the Tobacco Industry: All Smoke and Mirrors?", Accounting, Auditing and Accountability Journal, Vol. 18, No. 3, pp. 374-389.

O’Dwyer, B. (2005) "Stakeholder democracy: challenges and contributions from accountancy" Business Ethics: A European Review, Vol. 14, No. 1, pp. 28-41.

Owen, D.L. and O'Dwyer, B. (2005) “Assurance statement quality in environmental social and sustainability reporting: A critical examination", British Accounting Review, Vol. 37, No.2, pp. 205-230.

Owen, D.L., Swift, T.A., Humphrey, C. and Bowerman, M. (2000) "The New Social Audits: Accountability, Managerial Capture or the Agenda of Social Champions?", European Accounting Review, Vol. 9, No. 1, pp. 81-98.

Owen, D.L., Swift, T.A. and Hunt, K. (2001) "Questioning the role of stakeholder engagement in social and ethical accounting", Accounting Forum, Vol. 25 No. 3, pp. 264-282.

Pilger, J. (2004), Tell Me No Lies: Investigative Journalism and its Triumphs, Jonathan Cape.

Schlosser, E. (2002) Fast Food Nation, Penguin.

Shaoul, J. (1998) "Critical financial analysis and accounting for stakeholders", Critical Perspectives on Accounting, Vol. 9, pp. 235-249.

Stittle, J. (2002) "UK Corporate Ethical Reporting: A Failure to Inform: Some Evidence from Company Annual Reports”, Business and Society Review, Vol. 107, No. 3, pp. 349-370.

Swift, T. and Dando, N. (2002) "From methods to ideologies: Closing the assurance expectations gap in social and ethical accounting, auditing and reporting", Journal of Corporate Citizenship, Issue 8, pp. 81-90.

Tilt, C.A. (1994) "The influence of external pressure groups on corporate social disclosure: Some empirical evidence", Accounting, Auditing and Accountability Journal, Vol. 7, No. 4, pp. 47-72.

Thomson, I. and Bebbington, J. (2005), "Social and environmental reporting in the UK: A pedagogic evaluation", Critical Perspectives on Accounting, Vol. 16, No. 5, Pages 507-533.

Unerman, J. and Bennett, M (2004) "Increased stakeholder dialogue and the internet: Towards greater corporate accountability or reinforcing capitalist hegemony?", Accounting, Organizations and Society, Vol. 29, No. 7, pp. 685-707.

Zadek, S., Evans, R. and Pruzan, P. (1997) Building Corporate Accountability: Emerging Practice in Social and Ethical Accounting and Auditing, Earthscan. 